\title{
Wisata Halal Dalam Dimensi Kesantunan Tindak Tutur
}

\author{
${ }^{1}$ Habiburrahman, ${ }^{2}$ Nurmiwati, ${ }^{3}$ Akhmad H.Mus \\ 1,2,3Universitas Muhammadiyah Mataram, Mataram, Indonesia \\ 1habiburrahman@gmail.com, 2nurmiwati@gmail.com, 3akhmad@gmail.com
}

\begin{tabular}{|c|c|}
\hline Article Info & Abstract \\
\hline $\begin{array}{l}\text { Article History } \\
\text { Received: July 12, } 2018 \\
\text { Accepted: September 30, } \\
2018 \\
\text { Keywords } \\
\text { Wisata Halal; Kesantunan } \\
\text { Tindak Tutur }\end{array}$ & $\begin{array}{l}\text { Wisata halal yang umum dikenal selama ini adalah wisata syariah atau } \\
\text { wisata religi. Pengertiannya tentu tidak selalu berwisata ke lokasi-lokasi } \\
\text { religius seperti makam-makam Walisongo seperti yang selama ini banyak } \\
\text { dilakukan orang. Jika wisata religi lebih mengedepankan aspek lokasi atau } \\
\text { objek dan sejarah tempat wisata, maka wisata halal lebih mengedepankan } \\
\text { aspek pelaku atau wisatawannya. Istilah wisata halal tidak hanya soal } \\
\text { berkunjung ke lokasi religius, namun juga ke lokasi-lokasi umum dengan } \\
\text { tetap menjaga adab sebagai Muslim dan memberikan fasilitas serta } \\
\text { kemudahan bagi para wisatawan Muslim. Sesuai uraian tersebut maka } \\
\text { aspek kesantunan tindak tutur sebagai salah satu indikator wisata halal } \\
\text { dari aspek kemudahan komunikasi. Bagian tidak terpisahkan lainnya dari } \\
\text { wisata halal ini adalah para pemandu wisata yang juga harus } \\
\text { menyesuaikan diri dengan para wisatawan Muslim. Dalam komunikasi, } \\
\text { kesantunan merupakan aspek penting dalam kehidupan untuk menciptakan } \\
\text { komunikasi yang baik di antara pemandu wisata dan wisatawan. Misalnya } \\
\text { dengan menjaga adab berkomuniasi, menggunakan pakaian yang sopan } \\
\text { sesuai standar Muslim serta tidak lupa mengingatkan waktu beribadah } \\
\text { tepat waktu kepada para wisatawan dengan bahasa yang santun. Bentuk } \\
\text { kesantunan tindak tutur ini banyak kita temukan dalam sembilan fungsi } \\
\text { tindak tutur saat memberikan layanan sebagaimana hasil penelitian yang } \\
\text { dilakukan tentang penggunaan kesantunan tindak tutur direktif di kalangan } \\
\text { Jamaah Tablig dalam berdakwah, yaitu: (1) fungsi tindak tutur untuk } \\
\text { menyatakan ajakan, (2) suruhan, (3) peringatan, (4) seruan, (5) imbauan, } \\
\text { (6) persilaan, (7) anjuran, (8) harapan, dan (9) larangan. Pemakaian } \\
\text { kesantunan tindak tutur dalam memberikan layanan prima terhadap para } \\
\text { wisatawan dapat diklasifikasikan menjadi dua, yaitu strategi kesantunan } \\
\text { positif dan strategi kesantunan negatif. Kedua strategi kesantunan tersebut } \\
\text { dapat menjadi indikator wisata halal dari aspek kemudahan komunikasi } \\
\text { dengan menjaga adab berkomunikasi dan menciptakan situasi yang } \\
\text { nyaman dengan lingkungan yang santun dari masyarakatsekitarnya. }\end{array}$ \\
\hline $\begin{array}{l}\text { Support by: } \\
\text { dol Crossref }\end{array}$ & This is an open access article under the CC-BY-SA license \\
\hline
\end{tabular}

\section{PENDAHULUAN}

Wisata halal yang umum dikenal selama ini adalah wisata syariah atau wisata religi. Pengertiannya tentu tidak selalu berwisata ke lokasi-lokasi religius seperti makammakam Walisongo seperti yang selama ini banyak dilakukan orang. Jika wisata religi lebih mengedepankan aspek lokasi atau objek dan sejarah tempat wisata, maka wisata halal lebih mengedepankan aspek pelaku atau wisatawannya. Istilah wisata halal yang kemudian muncul inipun mendunia. Wisata halal ini memiliki cakupan yang lebih luas lagi. Tak hanya soal berkunjung ke lokasi religius, namun juga ke lokasi-lokasi umum dengan tetap menjaga adab sebagai Muslim dan memberikan fasilitas serta kemudahan bagi para wisatawan Muslim. 
Akademisi M. Battour dan M. Nazari Ismail mendefinisikan wisata halal sebagai berikut: Semua objek atau tindakan yang diperbolehkan menurut ajaran Islam untuk digunakan atau dilibati oleh orang Muslim dalam industri pariwisata. Definisi ini memandang hukum Islam (syariah) sebagai dasar dalam penyediaan produk dan jasa wisata bagi konsumen (dalam hal ini adalah Muslim), seperti hotel halal, resort halal, restoran halal dan perjalanan halal.

Menurut definisi ini, lokasi kegiatan tidak terbatas di negara-negara Muslim semata. Juga mencakup barang dan jasa wisata yang dirancang untuk wisatawan Muslim di negara Muslim dan negara non-Muslim. Selain itu, definisi ini memandang bahwa tujuan perjalanan tidak harus bersifat keagamaan. Jadi perjalanan bisa dengan motivasi wisata umum. Ada 6 kebutuhan pokok wisatawan Muslim yang diidentifikasi dalam studi Crescent Rating di 130 negara yaitu: 1) makanan halal, 2) fasilitas salat, 3) kamar mandi dengan air untuk wudhu, 4). pelayanan saat bulan Ramadhan, 5) pencantuman label non halal (jika ada makanan yang tidak halal), dan 6) fasilitas rekreasi yang privat (tidak bercampur baur secara bebas)

Berdasarkan Global Muslim Travel Index (GMTI) yang menjadi acuan standar wisata halal di dunia, bisa dirincikan kurang lebih sebagai berikut. Tiga kelompok kriteria wisata halal yang diulas adalah: 1) destinasi ramah keluarga, 2) layanan dan fasilitas di destinasi yang ramah muslim,dan 3) kesadaran halal dan pemasaran destinasi.

Lalu dari tiga kriteria ini, ada 11 indikator turunan yang menjadi acuannya. Untuk kriteria pertama, Destinasi Ramah Keluarga: 1) Destinasi wisata harus ramah keluarga. 2) keamanan umum bagi wisatawan Muslim. 3) jumlah kedatangan wisatawan muslim yang cukup ramai.

Untuk kriteria kedua, layanan dan fasilitas di destinasi yang ramah muslim: 4) pilihan makanan dan jaminan halalnya, 5) akses ibadah yang mudah dan baik, 6) fasilitas di bandara yang ramah Muslim, 7) serta opsi akomodasi yang memadai.

Untuk kriteria tiga, kesadaran halal dan pemasaran destinasi: 8) kemudahan komunikasi, 9) jangkauan dan kesadaran kebutuhan wisatawan muslim, 10) konektivitas transportasi udara, 11) Serta persyaratan visa.

Untuk memenuhi 11 indikator tersebut, sebuah destinasi wisata halal harus memiliki komitmen di tingkat pemangku kepentingan dan masyarakat, dalam hal ini adalah pemerintah. Kemudian lokasi yang bisa dimasuki oleh seluruh anggota keluarga, ayah-ibu dan anak. Lalu segi keamanan umum oleh kepolisian, satpam dan jajarannya. Sementara untuk jumlah kedatangan wisatawan muslim sendiri bisa melihat data dari data Kemenpar, Parekraf, Imigrasi dan Bandara.

Yang tidak kalah penting adalah pilihan makanan dan jaminan halal yang menjadi komitmen restoran dan penyedia makanan lainnya. Juga akses ke rumah ibadah dan kesadaran masyarakat untuk menjaga kebersihannya. Selanjutnya fasilitas di bandara yang dilengkapi dengan tempat ibadah yang layak. Kemudian pilihan akomodasi seperti transportasi dan hotel yang sesuai dengan wisatawan Muslim tentunya. Misalnya tersedianya perlengkapan ibadah serta penujuk arah kiblat di kamar hotel serta toilet yang menggunakan air.

Kemudahan komunikasi dengan menyediakan jasa translator Arab untuk wisatawan Timur Tengah, serta bahasa lainnya dari Asia, Eropa dll. Ditambah lagi dengan jangkauan dan kesadaran kebutuhan wisatawan Muslim oleh masyarakat setempat, konektivitas transportasi udara oleh maskapai dan persyaratan visa oleh bagian keimigrasian.

Bagian tidak terpisahkan lainnya dari wisata halal ini adalah para pemandu wisata yang juga harus menyesuaikan diri dengan para wisatawan Muslim. Misalnya dengan 
menjaga adab berkomuniasi, menggunakan pakaian yang sopan sesuai standar Muslim serta tak lupa mengingatkan waktu beribadah tepat waktu kepada para wisatawan.

Beranjak dari uraian tersebut, tugas yang diemban oleh pemandu wisata mesti harus memperhatikan pemakaian kesantunan tindak tutur dalam memberikan layanan dalam kemudahan komunikasi. Kondisi ideal sebagai bentuk pemakaian kesantunan tindak tutur ditemukan pemakaiannya dalam memandu wisata. Saat ini pemandu wisata memiliki eksistensi yang senantiasa berkomitmen memberikan layanan yang ramah dalam kondisi masyarakat yang beragam dengan pendekatan yang santun dan tidak memaksa.

Dua ahli filosofi, Jhon Austin dan Jhon Searle mengembangkan teori tindak tutur dari keyakinan dasar bahwa bahasa digunakan untuk melakukan tindakan. Jadi, faham fundamentalnya berfokus pada bagaimana makna dan tindakan dihubungkan dengan bahasa (Ibrahim, 2005:220).

Dengan demikian, menurut Austin, mengucapkan sesuatu adalah melakukan sesuatu dan di situ ada tindak tutur. Bahasa dapat digunakan untuk "membuat kejadian" (Sumarsono, 2009: 181). Berdasarkan pendapat para ahli di atas, dapat disimpulkan bahwa tindak tutur adalah tindakan yang dinyatakan dengan makna atau fungsi (maksud dan tujuan) yang melekat pada tuturan. Tindak tutur merupakan unit terkecil aktivitas bertutur (percakapan atau wacana) yang terjadi dalam interaksi sosial.

Relasi perwujudan kesantunan di dalam kajian ini dikelompokkan menjadi enam tipe atau kategori sejalan dengan pendapat Prayitno (2011:42). Keenam kategori ini kemudian dinamai sebagai kategori atau tipe derajat kedirektifan kesantunan. Di mulai dari derajat kesantunan direktif yang paling direktif yaitu tindak tutur direktif yang menghendaki dilakukannya suatu tindakan secara langsung sampai dengan derajat direktif yang kurang direktif, yaitu tindak tutur direktif yang menghendaki dilakukannya suatu tindakan secara tidak langsung. Keenam kategori TTD tersebut adalah sebagai berikut.

1) Tipe memerintah, meliputi sub-TTD memerintah, menyuruh, menginstruksikan, mengharusan, memaksa, meminjam, dan menyilakan.

2) Tipe meminta, meliputi sub-TTD meminta, mengharap, memohon, dan menawarkan.

3) Tipe mengajak, meliputi sub-TTD mengajak, membujuk, merayu, mendorong, mendukung, mendesak, menuntut, menantang, menagih, dan menargetkan.

4) Tipe memberi nasihat, meliputi sub-TTD menasihati, menganjurkan, menyarankan, mengarahkan, mengimbau, menyerukan, dan mengingatan.

5) Tipe mengkritik, meliputi sub-TTD menegur, menyindir, mengumpat, mengecam, dan marah.

6) Tipe melarang, meliputi sub-TTD melarang dan mencegah.

Sopan santun sering diartikan secara dangkal sebagai suatu 'tindakan yang sekadar beradab' saja, namun makna yang lebih penting yang diperoleh dari sopan santun ialah, sopan santun merupakan mata rantai yang hilang antara $\mathrm{Pk}$ dengan masalah bagaimana mengaitkan daya dengan makna (Leech, 1982:161).

Teori 'kesantunan' dalam penelitian ini dibedakan dengan 'kesopanan' dalam kajian sosiolinguitik. Kesopanan linguistik memang ditentukan secara kultural. Jelasnya, kaidah-kaidah untuk berperilaku yang sopan berbeda antara satu masyarakat tutur yang satu dengan masyarakat tutur yang lain. Masyarakat tutur yang berbeda memberikan penekanan pada fungsi-fungsi yang berbeda dan mengekspresikan fungsifungsi tertentu secara berbeda pula (Holmes, tanpa tahun:271). 


\section{METODE}

Metode yang digunakan dalam penelitian ini adalah

\section{HASIL DAN PEMBAHASAN}

Penulis akan membahas beberapa hal tentang wisata halal dalam dimensi kesantunan tindak tutur. Pemakaian kesantunan tindak tutur dalam wisata halal di kalangan pemandu wisata dapat diuraikan menjadi 2 bagian, yaitu: 1) penggunaan fungsi tindak tutur di kalangan pemandu wisata; 2) penggunaan strategi kesantunan tindak tutur di kalangan pemandu wisata. Secara terperinci, hal tersebut dibahas secara mendalam sebagai berikut.

\section{Fungsi Tindak Tutur di Kalangan Pemandu Wisata dalam Wisata Halal}

Pemakaian fungsi tindak tutur di kalangan pemandu wisata dalam wisata halal dapat diklasifikasikan menjadi 9 fungsi, yaitu untuk menyatakan ajakan, suruhan, peringatan, seruan, imbauan, persilaan, anjuran, harapan, dan larangan. Keterlibatan konteks pemakaian fungsi tindak tutur yang dimaksudkan tersebut pada dasarnya diklasifikasikan sesuai dengan kegiatan pemandu wisata dalam memberikan pelayanan prima kepada wisatawan sebagaimana dijelaskan secara terperinci pemakaian beserta interpretasi yang mendasari analisisnya.

1) Fungsi tindak tutur untuk menyatakan ajakan. Tuturan tersebut digunakan oleh pemandu wisata untuk mengajak wisatawan ikut melaksanakan dan mengindahkan dan menjaga lingkungan sekitar lokasi wisata. Demikian juga saat datangnya waktu shalat, pemandu wisata dapat mengajak wisatawan melaksanakan shalat di masjid dan melakukan kebaikan-kebaikan yang lain.

2) Fungsi tindak tutur untuk menyatakan suruhan. Pemakaian fungsi ini di kalangan pemandu wisata dalam berwisata hanya dipakai untuk internal selama berwisata. Fungsi tindak tutur tersebut sering dituturkan oleh ketua rombongan pemandu wisata untuk mengarahkan wisatawan saat mengikuti kegiatan berwisata dengan menaati peraturan selama berwisata dengan memperhatikan waktu dan ketentuan dalam berwisata seperti menjaga pakaian dalam berwisata di tempat religi.

3) Fungsi tindak tutur untuk menyatakan peringatan. Tuturan tersebut disampaikan untuk mengingatkan wisatawan tentang beberapa hal, seperti mengingatkan waktu istirahat, mengingatkan waktu makan, mengingatkan waktu shalat, dan mengingatkan habisnya waktu berkunjung atau bergantinya tempat berkunjung.

4) Fungsi tindak tutur untuk menyatakan seruan. Tuturan ini biasa dipakai di kalangan pemandu wisata saat memberikan apresiasi terhadap apa yang dilakukan oleh wisatawan atau apa yang dia kenakan, seperti ucapan selamat, ucapan kata bagus atau ucapan yang mengandung arti apresiasi.

5) Fungsi tindak tutur untuk menyatakan imbauan. Tuturan tersebut sering dipakai di kalangan pemandu wisata saat hendak mendampingi wisatawan dalam perjalanan berwisata dengan tetap memberikan imbauan kepada wisatawan sebagai bagian dari informasi penting yang harus diperhatikan oleh para wisatawan.

6) Fungsi tindak tutur untuk menyatakan persilaan. Tuturan tersebut dipakai di kalangan pemandu wisata saat memberikan kesempatan kepada wisatawan untukmelakukan sesuatu atau menikmati suatu fasilitas.

7) Fungsi tindak tutur untuk menyatakan anjuran. Pemakaian fungsi tindak tutur tersebut jarang ditemukan pemakaiannya karena bergantung pada konteks 
ditemukannya adanya penyimpangan dalam kegiatan berwisata atau adanya permintaan pendapat atau pandangan dari wisatawan kepada pemandu wisata.

8) Fungsi tindak tutur untuk menyatakan harapan. Pemakaian tuturan ini biasanya dituturkan dengan maksud untuk menyampaikan harapan kepada anggota wisatawan agar memperhatikan waktu atau ketentuan berwisata sebagai upaya penguatan system nilai yang harus dijaga oleh wisatawan.

9) Fungsi tindak tutur untuk menyatakan larangan. Pemakaian tuturan ini biasanya dituturkan dengan maksud untuk menyampaikan larangan secara langsung tentang apa saja yang mesti harus dijauhi oleh wisatawan. Larangan tersebut disampaiakan kepada wisatawan semata-mata agar tidak jatuh dalam perbuatan tercela atau menyalahi ketentuan yang berlaku.

\section{Strategi KesantunanTindak Tutur di Kalangan Pemandu Wisata dalam Berwisata}

Sesuai dengan pejelasan beberapa bentuk kegiatan pemandu wisata dalam mendampingi wisatawan, maka konteks pemakaian strategi kesantunan tindak tutur dalam berwisata juga mendasari kajian kesantunan ini. Pemakaian kesantunan tindak tutur dalam berwisata dapat diklasifikasikan menjadi 9 strategi kesantunan seperti disebutkan sebagai berikut: 1) melibatkan penutur dan mitratutur dalam aktivitas (Strategi positif); 2) menunjukkan keoptimisan (Strategi Positif); 3) memberikan tawaran atau janji (Strategi Positif); 4) manggunakan penanda identitas kelompok (seperti bentuk sapaan, dialek, jargon atau slang) (Strategi Positif); 5) pakailah bentuk impersonal, yaitu dengan tidak menyebutkan penutur dan mitratutur (Strategi negatif); 6) menyatakan paham atau mengerti akan keinginan mitratutur (Strategi Positif); 7) berikan penghormatan (Strategi Negatif); 8) membesar-besarkan perhatian, persetujuan, dan simpati kepada mitratutur (Strategi Positif); 9) menyatakan tindakan pengancam muka sebagai aturan yang bersifat umum (Strategi Negatif).

Sembilan strategi kesantunan tindak tutur tersebut dijelaskan secara terperinci pemakaian beserta interpretasi yang mendasari analisisnya.

1) Melibatkan penutur dan mitratutur dalam aktivitas (Strategi positif). Strategi kesantunan semacam ini dapat menghilangkan pembatas antara penutur dan mitra tutur, dalam hal ini yang dimksudkan adalah batasan antara wisatawan dan pemandu wisata dalam melaksanakan shalat atau kegiatan kebaikan yang lainnya.

2) Menunjukkan keoptimisan (Strategi Positif). Dalam hal ini koordinator pemandu wisata menggunakan strategi positif dengan menunjukkan keoptimisan dengan maksud bahwa para wisatawan dapat melakukan kegiatan berwisata dengan baik dan lancar sesuai yang diharapkan.

3) Memberikan tawaran atau janji (Strategi Positif). Dalam hal ini keuntungan yang ditawarkan kepada wisatawan apabila mengikuti anjuran pemandu wisata adalah berupa kenyamanan berwisata. Strategi ini semata-mata untuk menarik simpati mitra tutur agar mengikuti tuturannya.

4) Menyatakan paham atau mengerti akan keinginan mitratutur (Strategi Positif). Dalam hal ini, yang dimaksud adalah pemandu wisata memahami kondisi-kondisi wisatawan sehingga pemandu wisata lebih peka dengan keiginan dan harapan wisatawan.

5) Manggunakan penanda identitas kelompok (seperti bentuk sapaan, dialek, jargon atau slang) (Strategi Positif). Dalam hal ini, penanda identitas kelompok yang digunakan adalah dengan menggunakan kata "saudara atau sapaan yang akrab bagi wisatawan".

6) Pakailah bentuk impersonal, yaitu dengan tidak menyebutkan penutur dan mitratutur (Strategi Negatif). Dalam hal ini penutur tidak menyebut penutur atau 
mitratutur tetapi menggunakan bentuk impersonal jamak yang akan mewakili seluruh wisatwan seperti kata "kita".

7) Berikan penghormatan (Strategi Negatif). Demikian halnya dalam berwisata, dengan memberikan penghormatan kepada wisatawan maka posisinya akan tinggi di hadapan pemandu wisata. Strategi ini efektif digunakan di kalangan agar kemuliaan wisatawan mendapat posisi yang tinggi.

8) Membesar-besarkan perhatian, persetujuan, dan simpati kepada mitratutur (Strategi Positif). Dalam hal ini pemandu wisata mencoba memberikan pemaparan aturan dan ketentuan yang harus diperhatikan.

9) Menyatakan tindakan pengancam muka sebagai aturan yang bersifat umum (Strategi Negatif). Strategi ini menyatakan bahwa tindakan mengancam muka yang dilakukan bukan merupakan sesuatu yang ingin dilakukan penutur terhadap pendengar, tetapi adalah sesuatu yang terpaksa dilakukan dengan alasan peraturan atau kewajiban. Artinya sifat tegas yang harus disampaikan oleh pemandu wisata agar wisatawan taat terhadap peraturan yang berlaku.

\section{SIMPULAN}

Fungsi tindak tutur di kalangan pemandu wisata dalam berwisata dapat diklasifikasikan menjadi 9 fungsi tindak tutur direktif seperti disebutkan sebagai berikut: (1) fungsi tindak tutur untuk menyatakan ajakan, (2) fungsi tindak tutur untuk menyatakan suruhan, (3) fungsi tindak tutur untuk menyatakan peringatan, (4) fungsi tindak tutur untuk menyatakan seruan, (5) fungsi tindak tutur untuk menyatakan imbauan, (6) fungsi tindak tutur untuk menyatakan persilaan, (7) fungsi tindak tutur untuk menyatakan anjuran, (8) fungsi tindak tutur untuk menyatakan harapan, dan (9) fungsi tindak tutur untuk menyatakan larangan.

Pemakaian kesantunan tindak tutur di kalangan pemandu wisata dalam berwisata dapat diklasifikasikan menjadi 9 strategi kesantunan seperti disebutkan sebagai berikut: 1) melibatkan penutur dan mitratutur dalam aktivitas (Strategi positif); 2) menunjukkan keoptimisan (Strategi Positif); 3) memberikan tawaran atau janji (Strategi Positif); 4) manggunakan penanda identitas kelompok (seperti bentuk sapaan, dialek, jargon atau slang) (Strategi Positif); 5) pakailah bentuk impersonal, yaitu dengan tidak menyebutkan penutur dan mitratutur (Strategi negatif); 6) menyatakan paham atau mengerti akan keinginan mitratutur (Strategi Positif); 7) berikan penghormatan (Strategi Negatif); 8) membesar-besarkan perhatian, persetujuan, dan simpati kepada mitratutur (Strategi Positif); 9) menyatakan tindakan pengancam muka sebagai aturan yang bersifat umum (Strategi Negatif).

\section{DAFTAR PUSTAKA}

[1] Holmes, Janet. Tanpa Tahun. An Introduction to Sosiolinguitics (Terjemahan). Tidak Diterbitkan.

[2] Ibrahim, Abd. Syukur. 2005. Kapita Selekta Pragmatik. PPs. Universitas Negeri Malang. Tidak diterbitkan.

[3] Leech, Geoffrey. 1982. Prinsip-prinsip Pragmatik (Terjemahan). Jakarta: Universitas Indonesia.

[4] Pranowo. 2012. Berbahasa Secara Santun. Yogyakarta: Pustaka Pelajar.

[5] Prayitno, Harun Joko. 2010. "Perwujudan Prinsip Kerja Sama, Sopan Santun, dan Ironi Para Pejabat dalam Peristiwa Rapat Dinas di Lingkungan Pemerintahan Kota Berbudaya Jawa" dalam jurnal terakreditasi Kajian Linguistik dan Sastra, Volume 22, No.1, Juni 2010, Jurusan Pendididkan Bahasa Inggris dan Indonesia FKIP UMS. 
[6]__.2011. Kesantunan Sosiopragmayik: Studi Pemakaian Tindak tutur direktif di Kalangan Andik SD Berbudaya Jawa. Surakarta: Muhammadiyah University Press Universitas Muhammadiyah Muhammadiyah Surakata.

[7] Sumarsono. 2010. Buku Ajar Pragmatik. Universitas Pendididkan Ganehsa 